\title{
An Assessment of the State of Maintenance of Public Hospital Buildings in Southwest Nigeria
}

Olumide Adenuga (Department of Building, University of Lagos, Lagos, Nigeria) and Abayomi Ibiyemi (Department of Estate Management, Lagos State Polytechnic, Lagos, Nigeria)

\begin{abstract}
This study examines the state of maintenance of public hospital buildings in Southwest Nigeria, and in the process identifies the significant difference(s) in the operational state of Federal and State-owned public hospitals within the study area. In achieving the aim, the study adopts a survey technique with a total of 552 questionnaires, comprising 206 sampled maintenance staff and 346 users of public hospitals. The survey covers 46 public hospitals representing $40 \%$ of the total number of public hospitals existing in Southwest Nigeria. The 46 public hospitals consist of all the 11 Federal-owned hospitals and 35 randomly selected State-owned. Data collected are analysed using the Kendall Coefficient of Concordance and Pearson Chisquare. The findings of the study reveal that the state of maintenance of public hospital buildings is good. While the structure/fabric and physical conditions are rated highly, the services are poorly rated. This study, which hypothesises that there is no difference in the state of maintenance, finds statistical difference in the performance of the services. It recommends that Federal and State governments address neglect in the services sector and plan their maintenance programmes more effectively.
\end{abstract}

Keywords: maintenance, public hospitals, services, Federal and State government, Nigeria.

\section{INTRODUCTION}

Government-operated public hospitals are to provide accessible, cost effective specialist services that are safe and respond to individual needs, with efficient health-care delivery regardless of geographic location. Public hospitals are usually large buildings that have significant impact on the environment and the economy of the surrounding community. The physical surroundings in hospitals constitute health problems in public health delivery (Dilani, 1999). Patients in a healthcare facility are often fearful and uncertain about their health, their safety, and their isolation from normal social relationships. The large and complex environment of a typical hospital further contributes to the stressful situation. While it is true that good patient care comes from dedicated individuals, it is equally true that the physical structures and hospital environment must be such that the safety and well being of patients are protected. The performance of hospital buildings and their components depends to a large extent on continuous and planned periodical maintenance (Shohet, 2003). Maintenance is the art of controlling the rate at which structures deteriorate towards a state of unserviceability and collapse (Smith, 2003).

Government-owned hospitals are confronted with unique challenges that threaten their existence. Through an examination of the history, characteristics, and structure of public hospitals, it is found that such institutions by their nature lack the capacity to compete in a market-driven economy (Stolzenberg, 2002). This deficiency is further found to originate from the institution's inherent government structure, which promotes inefficiencies and inflexibility through the imposition of bureaucratic impediments to operational effectiveness. In Nigeria, according to Onifade (2003), installed health facilities are as old as the hospitals themselves. Some of the medical equipment are unserviceable and need outright replacement. The colonial architecture in some of the older hospitals, which were hitherto famous for their sturdiness and functionality, has now become less attractive because of the general neglect of building maintenance. Overcrowding has also led to deterioration of these facilities. Patients in a healthcare facility are often fearful, uncertain about their health and safety. This study aims to investigate the state of maintenance management of public hospital buildings; and the major objective is to examine the physical conditions of public hospital buildings in Southwest Nigeria and find out if there are any differences between Federal and State-owned public hospitals.

\section{RESEARCH HYPOTHESIS AND SCOPE}

The hypothesis postulated for this study is that there is no significant difference or association between the operational state of maintenance of Federal and State hospital buildings in Southwest Nigeria.

The study covers all Federal Government University Teaching Hospitals, orthopaedic, psychiatric hospitals and randomly selected State hospitals in Southwest Nigeria. The scope of the work excludes impact analysis on existing and potential users of hospital facilities.

Hospital building maintenance managers will be able to upgrade their understanding of building maintenance core problems and be able to evolve proactive policies to guide their operations and performance evaluation. The study will also create awareness about the need for effective maintenance management within the public hospital environment.

\section{LITERATURE REVIEW}

Buildings are required to provide a conducive and safe environment for various human activities. The extent to which buildings provide the required environment for the required activity is a measure of the functionality of the building (Oladapo, 2005). Hospitals are the most complex of building types (Kliment, 2000). Each hospital is comprised of a wide range of services and functional units, such as diagnostic and treatment functions, hospitality functions, and the fundamental inpatient care or bedrelated functions.

Nous Hospital Consultants (2002) regarded a hospital as not a mere building, but a complex social institution, composed of many groups representing a wide variety of interests and diverse needs that utilise the services of various medical, paramedical and support personnel to render all needed health care to the patients in its custody. It employs a wide variety of modern technologies and engineering services to support the process of 
healthcare using numerous biological, pharmaceutical, chemical and bio-chemical substances. It handles the dynamics of life and death situations during the process of rendering healthcare. Streifel (2002), described a hospital building as a healing indoor environment needed in healthcare to prevent infection control. Ulrich (1992) described a hospital building to be a healthcare environment that should measurably improve patient outcomes, reduce or eliminate environmental stressors, provide positive distractions, enable social support and give a sense of control. The goal of every health institution is to provide patient care, and produce medical and health manpower. In furtherance of this goal, staff with expertise of the highest skill are motivated in an environment that is clean, conducive and patient friendly. Hospital buildings are places where care and cure should be available to the public, but due to lack of maintenance public hospital buildings have become a place where people working in the built environment and patients have allergic-like reactions to unspecified stimuli: reactions like dizziness, nausea, irritation of mucous membrane, eye and/or nasopharyngeal irritation and sensitivity to bad odour from human waste, poor toilet facilities, and insufficient cleaning methods (lyagba, 2005).

Smith (2003) stated that regardless of the location, size or budget, all hospital buildings should have certain common attributes: efficiency and cost-effectiveness, flexibility and expandability, therapeutic environment, cleanliness and sanitations, accessibility, controlled circulation, aesthetics, security, safety and sustainability. A functional design can promote skill, economy conveniences and comforts; a non-functional design can impede activities of all types, detract from quality of care, and raise costs to intolerable levels (Hardy and Lamner, 1996). Hospital buildings are characterised by major complexity and hospital operations are affected by rapid changes and trends. According to Johassen et al. (2001), the supply of health and care are continually changing world over and the speed of change is ever accelerating. Planning and design of hospital buildings on all levels are affecting society and patients, from issues of localisation, concept and town planning, down to architecture and patients and hospital employees close surroundings. The views of these authors concerning hospital buildings are very relevant to the present study. The definitions reveal that the public hospital system is rarely a system of choice but is merely the default provider when the primary system fails to meet a need.

\section{MANPOWER SOURCES FOR MAINTENANCE WORKS EXECUTION}

The execution of maintenance works is the practical realisation of all the management decisions, designs and dreams for maximising the results of maintenance efforts. According to Adebayo (1991), maintenance works are complex in nature and therefore are carried out by directly employed labour while some are carried out by contractors. Accordingly, the mode of execution of maintenance works is a matter of policy. It is the maintenance policy of the establishment that dictates whether directly employed labour, or contractors, or a combination of both, will be most advantageous. Lee (1987) states that the major problem confronting the maintenance manager is the decision on a particular method of executing maintenance works. According to him, some maintenance works must be handled by contractors and therefore the choice between direct and contract labour must be made.

Seeley (1987) stipulates that in reaching a decision, the maintenance manager should compare the costs and services provided by the contractors with his own directly employed labour force, taking into account the availability of labour and the type and location of the building to be maintained. Lee (1987), in accordance with this notion, contended that the choice should be made depending on which offers the greater advantage in terms of cost, quality and convenience. It is also noted that there are certain specialist maintenance works that should normally be handled by contractors. To the author, direct labour organisations will only function well where necessary facilities are provided. The Chartered Institute of Building (1975) reiterated that the sizes, types and number of buildings to be maintained will invariably determine the source of manpower either in service or outsourcing. Seeley (1987) reaffirms that successful execution of maintenance work, be it direct labour or by contract, depends on well detailed specifications, good planning and supervision.

Arditi (1997) stated the reasons for using in-house personnel to deliver maintenance services. Using in-house staff will give a better control of service levels. Along with service control, it reduces the costs of getting a higher quality of work and achieving more flexibility in staffing. There is a better adjustment to workload fluctuations. He believed that if managers have better control of the maintenance operations by using in-house staff, then they will also be able to keep costs down, ensure high quality works and respond to maintenance calls in a timely fashion by adjusting the size and the work schedules of their staff. Holland (1987), Lee (1987), Chanter and Swallow (1996), and the findings of Gregerson (1994) support this result. According to Arditi (1997), $61 \%$ of firms that outsource maintenance services use competitive bidding exclusively when selecting their contractors, whereas $23 \%$ use negotiation exclusively, and $16 \%$ use both. Competitive bidding is expected in principle to result in the most economical offer from a competent contractor, but the paper work involved in the process is sometimes overwhelming. According to Arditi, negotiation appeared to be a viable alternative, particularly for short term and low budget works.

lyagba (2005) stated that outsourcing holds the promise of flexibility and profitability, but there may be disadvantages that are not at all obvious. Another major attraction, as noted by the author, is that it allows the business to focus on its core business and competencies, leaving peripheral and support functions to be serviced by outside experts. For smaller employers, outsourcing also has the advantage of a reduction in staff numbers, possibly removing the business from the statutory thresholds of increased obligations, including submission of employment equity plans.

lyagba (2005) further stated that before a business embarks upon outsourcing there are a few potential downsides to consider. Firstly, he stated that the employers must contract only with reputable service providers with a proven track record of compliance and good human relation capability. Secondly, where outsourcing involves dismissal of staff that become redundant, it may contribute to the country's chronic unemployment problem. Thirdly, there is still uncertainty in legal circles over whether, and under what circumstances, outsourcing constitutes a transfer of a business as a going concern, so in using the method good legal advice should be obtained. Fourthly, employers sometimes outsource non-core functions to existing staff with the idea that they would become entrepreneurs by supplying expertise back to the old employer as independent contractors. A fifth problem is that the introduction of a service provider in the form of a labour broker may upset established relations and create friction between the employer's own employees and those of the service provider. Another less obvious problem is the fact that long-term exclusive outsourcing arrangements create a dependency that might isolate the organisation from the market. According to the author, by giving the vendor the exclusive right to understand one's business, one may be making it harder in the longer term to terminate the relationship. The vendor, may in turn, build up relationships with business peers 
and partners and become a surrogate in dealing with them. Unless the rules are clearly spelt out and the business makes an effort to maintain its visibility, there is a real risk of its relationships with them disappearing.

While outsourcing offers potential benefits in terms of cost, service levels and access to talent, it is a strategic decision requiring careful thought about risks, benefits and governance. Estates Good Practice (2005), in their research, showed that the unique nature of an institution's estates, its location, availability of craftsmen and the preference of the estate director will all feature in the choice between direct or contract workers. According to them, the success of the operation will rely on management, adequate supervision and quality control. It is unlikely it will prove desirable to dispense with in-house labour as there are many benefits to employing a small group of craftsmen directly, particularly if they are multi-skilled. These include: familiarity with the assets, understanding how the assets operate, awareness of the maintenance requirements, quick response time in the case of emergencies, aiding the security role, and personal commitment and loyalty to the institution. However there are disadvantages of employing in-house labour requiring consideration of the following issues:

- they are full-time appointments, and therefore sufficient work must be available to fully utilise them or they drain resources

- $\quad$ full training is required

- they can lack the simulation of other work and differing environments

Shohet (2003), in his examination of the proportion of maintenance works performed by outsourcing versus in-house provision in hospital buildings, reaffirmed that the choice of either method depends on the occupancy rate. He divides hospital into high occupancy hospitals (over ten patient beds per 1,000 $\mathrm{m}^{2}$ ) and hospitals with standard or low levels of occupancy (up to ten patient beds per $1,000 \mathrm{~m}^{2}$ ). From his regression analysis it was shown that when a hospital occupancy level is standard or low, outsourcing results in a saving of approximately $8 \%$ in maintenance expenditure. On the other hand when hospital occupancy levels are higher than planned, the use of in-house provision leads to a $6 \%$ saving in maintenance expenditure. This is due to the fact that the deterioration of some of the building systems under high occupancy conditions is accelerated, and a high availability of maintenance personnel is required for breakdown maintenance. Therefore, under such conditions, inhouse provision offers opportunity for savings.

This conclusion differs from that of previous studies on the subject (Hardy and Lammer, 1996). At standard or low occupancy levels, there is indeed an advantage as well as savings in the employment of a manpower composition in which the majority of the maintenance workers are external personnel. On the other hand, at high occupancy levels, there is a clear benefit from manpower compositions in which the majority of personnel are in-house maintenance workers.

\section{RESEARCH METHODS}

A total of 46 public hospitals in Southwest Nigeria, representing about $40 \%$ of government owned hospitals, were sampled for the study out of a total of 114 public hospitals (excluding health centres). The technique adopted, according to EasterbySmith (1991) as cited in Oladapo (2005), affords an objective measurement of the subject under analysis and facilitates replication (adoption and verification) by others. A stratified sampling method is used. The study population comprises the users who are the medical staff, administrative and management staff including the patients and the maintenance staff inclusive of maintenance technical staff and the maintenance manager/ engineer of the selected public hospitals in Southwest Nigeria. The response rate was $90.1 \%$ and $73 \%$ for Federal and State-owned hospitals respectively. This research focuses on the evaluation of maintenance management practices in public hospital buildings. The study area covers six States, namely Lagos (from which 9 public hospitals were chosen for the study), Ogun State (11), Ondo State (6), Ekiti Stae (6), Osun State (5) and Oyo State (9) respectively. The States are located within the same geographical zone and have similar social backgrounds. Analytical tools used for the study include the mean item score, percentages, ranking, Kendall Coefficient of Concordance and Pearson Chisquare for testing relationships at the Federal and State levels.

\section{DATA PRESENTATION AND ANALYSIS}

Table 1 indicates the sample selection from the sampling frame of Federal and State-owned hospitals in Southwest Nigeria. It can be concluded that the sampling distribution is representative. Table 2 indicates the distribution of respondents between Federal and State-owned hospitals. It can be concluded that the response rates achieved are very high. It is found that $51.4 \%$ of the maintenance staff are part of management and this indicates that maintenance staff are well represented at an organisational level. This should enhance the performance of the building as key decisions are made at this level. The remainder of maintenance staff (48.6\%) are technical. The use of the buildings for health care delivery varies. $74.1 \%$ of use is general hospital, $3.1 \%$ is anti-natal, $11.9 \%$ is post-natal, $6.2 \%$ is combined anti and post-natal, and $4.7 \%$ is other uses. From the analysis there is an indication that thee majority of hospitals examined operate their buildings for general treatment. There is a need for the development of more buildings for specialist treatment.

The length of service distributions presented in Table 3 indicates that the majority of the respondents have a working experience less than 10 years $(57.3 \%)$, while maintenance staff with better experience as evidenced by length of service are less than $15 \%$ (respondents with 20-30 years and above). This is an indicator that maintenance work execution may be lacking technical expertise in public hospitals.

Table 4 shows the number of buildings available for maintenance in public hospitals in Southwest Nigeria. Only $15 \%$ of the hospitals sampled have more than 30 buildings and above for their health care delivery system. This is an indication that the majority of the public hospitals have inadequate building stock for effective healthcare delivery. The complex nature of hospitals, with various medical treatments coupled with large attending population indicate that the existing building stock is not adequate for an effective healing environment for patients and staff.

Table 5 indicates the department of the users of public hospital buildings. $40 \%$ of the total population sampled was allocated to medical staff. The justification for this was that they constitute the highest percentage of workers in any hospital environment. This is followed by administrative staff $(30 \%)$ and management staff (10\%). Response from the patients was expectedly low (20\%). Table 6 reveals that $81.5 \%$ of the respondents have a limited working experience not more than 10 years in their department. Only about $18.5 \%$ of them had working experience of 11 years and above. 
Table 1: Sample frame for Federal and State-owned hospitals

\begin{tabular}{|l|c|c|c|c|c|c|}
\hline State & $\begin{array}{c}\text { No. of } \\
\text { Federal- } \\
\text { owned } \\
\text { hospitals }\end{array}$ & $\begin{array}{c}\text { No. } \\
\text { selected for } \\
\text { the study }\end{array}$ & $\begin{array}{c}\text { No. of } \\
\text { State- } \\
\text { owned } \\
\text { hospitals }\end{array}$ & $\begin{array}{c}\text { No. } \\
\text { selected } \\
\text { for the } \\
\text { study }\end{array}$ & $\begin{array}{c}\text { Total No. } \\
\text { selected for } \\
\text { the study }\end{array}$ & $\%$ \\
\hline Ekiti & 1 & 1 & 14 & 5 & 6 & 13.0 \\
\hline Osun & 1 & 1 & 11 & 4 & 5 & 10.9 \\
\hline Ondo & 2 & 2 & 13 & 4 & 6 & 13.0 \\
\hline Oyo & 1 & 1 & 21 & 8 & 9 & 19.6 \\
\hline Lagos & 4 & 4 & 18 & 5 & 9 & 19.6 \\
\hline Ogun & 2 & 2 & 26 & 9 & 11 & 23.9 \\
\hline Total & 11 & 11 & 103 & 35 & 46 & 100.0 \\
\hline
\end{tabular}

Table 2: Public hospital ownership

\begin{tabular}{|l|c|l|l|l|l|l|}
\hline & \multicolumn{2}{|c|}{ Maintenance Staff Response } & \multicolumn{3}{c|}{ Users Response } \\
\hline $\begin{array}{l}\text { Hospital } \\
\text { Ownership }\end{array}$ & $\begin{array}{l}\text { Sample } \\
\text { Size }\end{array}$ & $\begin{array}{l}\text { No. } \\
\text { returned }\end{array}$ & $\begin{array}{l}\text { Response } \\
\%\end{array}$ & $\begin{array}{l}\text { Sample } \\
\text { Size }\end{array}$ & $\begin{array}{l}\text { No. } \\
\text { returned }\end{array}$ & $\begin{array}{l}\text { Response } \\
\%\end{array}$ \\
\hline Federal owned & 55 & 46 & 78.2 & 110 & 78 & 70.9 \\
\hline State owned & 175 & 160 & 92 & 350 & 268 & 76.6 \\
\hline Total & 230 & 206 & $\begin{array}{l}90.1 \\
\text { (mean) }\end{array}$ & 460 & 346 & $\begin{array}{l}73.8 \% \\
\text { (mean) }\end{array}$ \\
\hline
\end{tabular}

Table 3: Analysis of maintenance staff length of service in public hospitals

\begin{tabular}{|l|c|c|c|}
\hline Length of service & Frequency & $\begin{array}{c}\text { Valid } \\
\text { percent }\end{array}$ & $\begin{array}{c}\text { Cumulative } \\
\text { percent }\end{array}$ \\
\hline Less than 10 years & 118 & 57.3 & 57.3 \\
\hline $10-19$ years & 63 & 30.6 & 87.9 \\
\hline $20-29$ years & 20 & 9.7 & 97.6 \\
\hline 30 and above & 5 & 2.4 & 100.0 \\
\hline Total & 206 & 100.0 & \\
\hline
\end{tabular}

Table 4: Analysis of the number of hospital building being managed by maintenance departments

\begin{tabular}{|l|c|c|c|}
\hline Number of buildings & Frequency & $\begin{array}{c}\text { Valid } \\
\text { percent }\end{array}$ & $\begin{array}{c}\text { Cumulative } \\
\text { percent }\end{array}$ \\
\hline $\begin{array}{l}\text { Fewer than } 5 \\
\text { buildings }\end{array}$ & 47 & 24.7 & 24.7 \\
\hline $6-10$ buildings & 21 & 11.1 & 35.8 \\
\hline $11-15$ building & 39 & 20.5 & 56.3 \\
\hline $21-30$ buildings & 40 & 21.1 & 84.7 \\
\hline $31-40$ buildings & 10 & 5.3 & 92.6 \\
\hline $41-50$ buildings & 5 & 2.6 & 100 \\
\hline More than 50 & 14 & 7.4 & \\
\hline Total & 190 & 100.0 & \\
\hline
\end{tabular}

Table 5: Ranking of the levels of use of selected project plans in public and private sector projects in Nigeria

\begin{tabular}{|l|c|c|c|c|}
\hline Department of the Users & $\begin{array}{c}\text { Sample } \\
\text { Size }\end{array}$ & $\begin{array}{c}\text { \% of the } \\
\text { population }\end{array}$ & $\begin{array}{c}\text { No. } \\
\text { Returned }\end{array}$ & $\begin{array}{c}\text { Response } \\
\%\end{array}$ \\
\hline Medical staff & 184 & 40 & 184 & 100 \\
\hline Administrative staff & 138 & 30 & 100 & 72.5 \\
\hline Management Staff & 46 & 10 & 30 & 65.2 \\
\hline Patients & 92 & 20 & 30 & 32.6 \\
\hline Total & 460 & 100 & 344 & 74.8 \\
\hline
\end{tabular}




\section{ANALYSIS OF THE OPERATIONAL STATE OF BUILDING ELEMENTS AND SERVICES}

Maintenance managers, technical staff of maintenance departments and the users of public hospital buildings were asked to rate the physical conditions and the state of accommodation in terms of the twenty-seven attributes mentioned below using a scale of (1) very bad, (2) bad, (3) average, (4) good, and (5) very good. The results obtained are shown in Table 7.

The results indicated that the building structure and fabrics (i.e. blockwalls, floor slabs, beams, columns and roof structure) are in good condition as perceived by the maintenance staff. They are rated best among others in terms of their state of maintenance.
From the users' perspective, only the floor slabs and block walls are rated to be in good condition. The results as indicated by the maintenance staff revealed that the positioning of the buildings and other services within the hospital environment in Southwest Nigeria created sufficient air circulation for efficient performance. This is observed in Table 7, with air circulation ranked second among others. The maintenance staff and users of public hospital buildings agreed that the level of cleanliness, the sanitation of the environment and the clean water supply are above average in their performance. Interior works (i.e. ceiling, doors, windows, internal painting, etc.) are also rated above average in their state of maintenance as perceived by both respondents. Indoor air-quality (humidity control) is rated better by the maintenance staff than the users who rated the performance very low, among. Other external

Table 6: Analysis of users of hospital buildings by length of service

\begin{tabular}{|c|c|c|c|}
\hline Length of service & Frequency & $\begin{array}{c}\text { Valid } \\
\text { percent }\end{array}$ & $\begin{array}{c}\text { Cumulative } \\
\text { percent }\end{array}$ \\
\hline Less than 2years & 100 & 29.1 & 29.1 \\
\hline $2-5$ years & 100 & 29.1 & 58.2 \\
\hline $6-10$ years & 80 & 23.3 & 81.5 \\
\hline $11-15$ years & 57 & 16.5 & 98.0 \\
\hline 16 years and above & 77 & 2.0 & 100.0 \\
\hline Total & 344 & 100.0 & \\
\hline
\end{tabular}

Table 7: Physical conditions of hospital buildings as perceived by maintenance officers and users

\begin{tabular}{|c|c|c|c|c|}
\hline \multirow{2}{*}{$\begin{array}{c}\text { Performance Criteria } \\
\text { Building } \\
\text { Elements/Services }\end{array}$} & \multicolumn{2}{|c|}{$\begin{array}{l}\text { Maintenance Staff } \\
\text { Response }\end{array}$} & \multicolumn{2}{|c|}{ Users Response } \\
\hline & Mean & Overall Ranking & Mean & Overall Ranking \\
\hline Block Walls & 4.14 & 1 & 3.83 & 3 \\
\hline Air circulation & 4.12 & 2 & 3.43 & 21 \\
\hline Floor Slabs & 4.12 & 2 & 3.94 & 2 \\
\hline Roof Structure & 4.09 & 4 & 3.79 & 6 \\
\hline Beams/Columns & 4.07 & 5 & 3.61 & 12 \\
\hline Level of Cleanliness & 4.03 & 6 & 3.95 & 1 \\
\hline $\begin{array}{l}\text { Sanitation of the } \\
\text { Environment }\end{array}$ & 3.98 & 7 & 3.79 & 6 \\
\hline Clean water supply & 3.97 & 8 & 3.8 & 5 \\
\hline Ceiling & 3.95 & 9 & 3.81 & 4 \\
\hline Doors & 3.87 & 10 & 3.76 & 9 \\
\hline Windows & 3.87 & 10 & 3.77 & 8 \\
\hline Internal Painting & 3.86 & 12 & 3.69 & 10 \\
\hline $\begin{array}{l}\text { Indoor Air Quality } \\
\text { (Humidity Control) }\end{array}$ & 3.86 & 12 & 3.39 & 23 \\
\hline Noise Protection & 3.83 & 14 & 3.55 & 17 \\
\hline Floor/Wall Tiles & 3.81 & 15 & 3.67 & 11 \\
\hline External Painting & 3.8 & 16 & 3.6 & 13 \\
\hline Drains & 3.78 & 17 & 3.6 & 13 \\
\hline Waste water Disposal & 3.75 & 18 & 3.46 & 19 \\
\hline Security & 3.74 & 19 & 3.45 & 20 \\
\hline Human Traffic Control & 3.69 & 20 & 3.43 & 21 \\
\hline Garbage Disposal & 3.66 & 21 & 3.5 & 18 \\
\hline Sanitary Fittings & 3.6 & 22 & 3.6 & 13 \\
\hline Nettings & 3.6 & 22 & 3.6 & 13 \\
\hline Electricity Supply & 3.6 & 22 & 3.39 & 23 \\
\hline $\begin{array}{l}\text { Telecommunication } \\
\text { Systems }\end{array}$ & 3.59 & 25 & 3.19 & 27 \\
\hline Fire Protection & 3.56 & 26 & 3.28 & 26 \\
\hline $\begin{array}{l}\text { Lifts (Vertical } \\
\text { Transportation) }\end{array}$ & 3.36 & 27 & 3.38 & 25 \\
\hline
\end{tabular}


services such as noise control, drains, wastewater disposal, security, human traffic control and garbage disposal were also rated as good in their operational state. Services such as vertical transportation (lifts), fire protection, telecommunication systems and electricity supply were both rated very low among others by both the maintenance staff and users of public hospital buildings in Southwest Nigeria.

Table 8 indicated that the maintenance staff of both Federal and State-owned hospitals shared the same opinion in their responses. Both groups rated the structure and fabrics (block walls, floor slabs, beams/columns and roof structure) as best among others in their operational state. They both agreed that the location of buildings within the hospital environment, level of cleanliness and clean water supply are good. Vertical transportation (lifts), telecommunication systems and electricity supply were rated least among others by the maintenance staff of both institutions. External services such as waste disposal, drains and security provisions are better in operation in the Federal-owned hospitals than thse that are State-owned. Also, noise control and garbage disposal are both rated above average in their operational state with better performance in the Federalowned hospitals than their State counterparts. The users of hospital buildings in both Federal and State-owned hospitals ranked the level of cleanliness of hospital environment as best among other operations. Users in both institutions rated the existing air circulation within the environment very low as against the opinion of maintenance staff of both institutions. Structures and fabrics were rated above average in their performance, except the floor slab rated as average in the State-owned hospitals. The use of lifts, telecommunication systems, and electricity supply were rated as least amongst other criteria.

Table 8: Physical conditions of building elements and services

\begin{tabular}{|c|c|c|c|c|c|c|c|c|}
\hline \multirow{2}{*}{$\begin{array}{c}\text { Building } \\
\text { Elements/Services } \\
\text { (Performance } \\
\text { Criteria) }\end{array}$} & \multicolumn{4}{|c|}{ Federal owned hospitals } & \multicolumn{4}{|c|}{\begin{tabular}{|c|} 
State owned hospitals \\
\end{tabular}} \\
\hline & \begin{tabular}{|c|} 
Maintenance \\
Staff \\
Response \\
\end{tabular} & Ranking & \begin{tabular}{|c|} 
User's \\
Response
\end{tabular} & Ranking & \begin{tabular}{|c|} 
Maintenance \\
Staff \\
Response \\
\end{tabular} & \begin{tabular}{|l|} 
Ranking \\
\end{tabular} & \begin{tabular}{c|} 
User's \\
Response
\end{tabular} & Ranking \\
\hline Block Walls & 4.27 & 1 & 3.81 & 6 & 4.00 & 4 & 3.85 & 4 \\
\hline Air Circulation & 4.23 & 2 & 3.44 & 23 & 4.01 & 3 & 3.41 & 20 \\
\hline Floor Slab & 4.21 & 3 & 4.01 & 2 & 4.03 & 1 & 3.38 & 22 \\
\hline Beams/Columns & 4.21 & 3 & 3.58 & 18 & 3.93 & 8 & 3.65 & 11 \\
\hline Roof Structure & 4.15 & 5 & 3.88 & 3 & 4.03 & 1 & 3.71 & 9 \\
\hline $\begin{array}{l}\text { Sanitary Of the } \\
\text { Environment }\end{array}$ & 4.08 & 6 & 3.84 & 5 & 3.86 & 12 & 3.74 & 7 \\
\hline $\begin{array}{l}\text { Clean Water } \\
\text { Supply }\end{array}$ & 4.07 & 7 & 3.87 & 4 & 3.87 & 11 & 3.73 & 8 \\
\hline $\begin{array}{l}\text { Level Of } \\
\text { Cleanliness }\end{array}$ & 4.04 & 8 & 4.05 & 1 & 3.99 & 5 & 3.86 & 2 \\
\hline Ceiling & 3.98 & 9 & 3.65 & 13 & 3.94 & 7 & 3.97 & 1 \\
\hline $\begin{array}{l}\text { Indoor Air Quality } \\
\text { (humidity) }\end{array}$ & 3.94 & 10 & 3.77 & 8 & 3.79 & 13 & 3.01 & 26 \\
\hline $\begin{array}{l}\text { Waste water } \\
\text { Disposal }\end{array}$ & 3.93 & 11 & 3.64 & 14 & 3.56 & 20 & 3.28 & 24 \\
\hline Drains & 3.91 & 12 & 3.53 & 19 & 3.66 & 18 & 3.67 & 10 \\
\hline Security & 3.89 & 13 & 3.42 & 25 & 3.59 & 19 & 3.48 & 18 \\
\hline Security & 3.89 & 13 & 3.42 & 25 & 3.59 & 19 & 3.48 & 18 \\
\hline Noise protection & 3.89 & 13 & 3.61 & 16 & 3.77 & 14 & 3.49 & 16 \\
\hline Windows & 3.87 & 15 & 3.72 & 10 & 3.88 & 10 & 3.82 & 5 \\
\hline $\begin{array}{l}\text { Human Traffic } \\
\text { Control }\end{array}$ & 3.87 & 15 & 3.37 & 27 & 3.51 & 22 & 3.49 & 16 \\
\hline Floor/Wall Tiles & 3.87 & 15 & 3.74 & 9 & 3.75 & 15 & 3.61 & 13 \\
\hline External Painting & 3.86 & 18 & 3.8 & 7 & 3.75 & 15 & 3.4 & 21 \\
\hline Garbage Disposal & 3.81 & 19 & 3.49 & 19 & 3.51 & 22 & 3.51 & 15 \\
\hline Fire Protection & 3.78 & 20 & 3.52 & 21 & 3.34 & 26 & 3.05 & 25 \\
\hline Doors & 3.76 & 22 & 3.72 & 10 & 3.98 & 6 & 3.81 & 6 \\
\hline Sanitary Fittings & 3.75 & 23 & 3.72 & 10 & 3.45 & 25 & 3.47 & 17 \\
\hline Electricity Supply & 3.71 & 24 & 3.59 & 17 & 3.5 & 24 & 3.59 & 14 \\
\hline $\begin{array}{l}\text { Telecommunication } \\
\text { Systems }\end{array}$ & 3.64 & 25 & 3.40 & 26 & 3.55 & 21 & 2.98 & 27 \\
\hline $\begin{array}{l}\text { Nettings } \\
\text { Vertical }\end{array}$ & 3.58 & 26 & 3.63 & 14 & 3.67 & 17 & 3.62 & 12 \\
\hline $\begin{array}{l}\text { Transportation } \\
\text { (lifts) }\end{array}$ & 3.41 & 27 & 3.44 & 23 & 3.31 & 27 & 3.33 & 23 \\
\hline
\end{tabular}




\section{HYPOTHESIS TESTING}

To further verify the differences in the ranking of the operational state of the building elements and services by both sets of respondents, Pearson's Chisquaret-test and Kendall's Tau Rank Correlation were used (see Table 9 below). A Kendall Coefficient of Concordance of $-0 . .310$ was determined, signifying a weak relationship between the maintenance staff responses and the users. The Pearson Chisquare statistic is 22.502 with a p-value (Asymp sig. 2 sided) of .001. The result for the Pearson Chisquare at $p(.001)<\alpha(0.01)$ shows that there is statistical difference in the rating of the operational state of building elements and services by the maintenance staff and the users of public hospital buildings in Southwest Nigeria.

The mean for the operational state of Federal and State-owned hospital buildings are above average in physical conditions with the Federal hospitals having a higher value of 3.97 compared to the State hospitals (3.69). The Kendall Coefficient of Concordance test for the operational state of building elements/ services between Federal and State-owned hospitals are also shown in Table 9.

Therefore it can be concluded that the relationship between the operational states is significant. The null hypothesis $\mathrm{H}_{0}$, which states there is no significant difference in the operational state of buildings between Federal and State-owned hospitals in Southwest Nigeria is therefore rejected, and the alternate hypothesis $\mathrm{H}_{1}$, which states there is a significant difference in the operational state of buildings between Federal and State-owned hospitals in Southwest Nigeria, is accepted.

\section{PHYSICAL CONDITIONS OF PUBLIC HOSPITAL BUILDINGS}

Southwest Nigeria actually consists of six States, comprising Lagos, Ogun, Oyo, Osun, Ekiti and Ondo. The physical condition of buildings is examined in terms of building structures and fabrics (floor slab, roof, block walls, columns and beams); services (water supply, electricity supply, telecommunication systems, sanitary appliances, humidity control, lifts) and the environment they are operating. The physical condition of the building elements and the services in each State are as discussed below and as summarised in Table 10.
LAGOS STATE

The building structure and fabrics are rated above average in performance. They are ranked better in their state of maintenance than the building services which were ranked very low in performance. The use of lifts for vertical transportation was rated to be very bad while noise control, telecommunication systems, humidity control, fire protection, the drains and waste disposal were rated average in performance. The level of cleanliness of the surroundings ranked first among others. It is rated good considering the physical condition. This is an indication that more resources are needed from the government for the supply of necessary services to public hospitals in Lagos State if greater efficiencies are to be achieved without compromising the core business of the hospital, which is to treat and cure patients.

\section{OGUN STATE}

Building structure and fabrics are rated above average in their state of maintenance. They are also rated better than the building services. The maintenance performance of lifts was rated very poor, while telecommunications systems, fire protection devices, and human traffic control were rated below average in performance. There is insufficient air circulation for efficient performance due to the arrangement of buildings within the hospital environment. It is rated below humidity control, fire protection, and garbage disposal. Electricity supply and clean water supply were rated average in performance. This is a reflection that public hospitals in Ogun State need immediate attention if they are to provide cost effective and specialist services that are safe and of high quality. Ventilation plays a role in infectious disease management as clusters of infections have been reported in facilities due to an imbalance in ventilation systems from a lack of mechanical control. Necessary services should be provided to reduce the mortality rate.

\section{OYO STATE}

The arrangement of buildings in public hospitals in the Oyo State creates conducive air circulation for efficient performance of the buildings and the services being rendered. Humidity control, sanitation of the environment considering the level of cleanliness and noise protection are all rated good in their performance. They are ranked best among other factors considered. The services such as provision of security, fire protection, electricity

Table 9: Pearson's Chisquare result and Kendall's Coefficient of Concordance test for the operational state of building elements and services

\begin{tabular}{|l|l|l|l|l|}
\hline & Statistic & $\alpha$ & $\mathrm{dF}$ & Asymp sig. \\
\hline $\begin{array}{l}\text { Pearson's } \\
\text { Chi-square }\end{array}$ & 22.502 & .01 & 4 & .001 \\
\hline $\begin{array}{l}\text { Likelihood } \\
\text { Ratio }\end{array}$ & 20.295 & & 4 & .002 \\
\hline $\begin{array}{l}\text { Linear by } \\
\text { Linear } \\
\text { Association }\end{array}$ & 1.003 & & 1 & .310 \\
\hline $\begin{array}{l}\text { No. of valid } \\
\text { cases }\end{array}$ & 549 & & & \\
\hline \multicolumn{4}{|l|}{ Coefficient of Concordance } \\
\hline
\end{tabular}


Table 10: Operational state of building elements and services in public hospitals

\begin{tabular}{|c|c|c|c|c|c|c|c|c|c|c|c|c|}
\hline $\begin{array}{l}\text { BUILDING } \\
\text { ELEMENTS / } \\
\text { SERVICES } \\
\end{array}$ & Lagos & ranking & Ogun & ranking & Oyo & ranking & Osun & ranking & Ekiti & ranking & Ondo & ranking \\
\hline Level of cleanliness & 3.89 & 1 & 3.65 & 5 & 4.08 & 4 & 3.52 & 8 & 3.65 & 7 & 3.69 & 14 \\
\hline \multirow{2}{*}{$\begin{array}{l}\text { Floor slabs } \\
\text { Sanitation of the } \\
\text { environment }\end{array}$} & 3.82 & 2 & 3.80 & 1 & 3.96 & 6 & 3.74 & 3 & 4.14 & 1 & 3.93 & 5 \\
\hline & 3.78 & 3 & 3.41 & 11 & 4.19 & 3 & 3.57 & 7 & 3.27 & 20 & 4.13 & 1 \\
\hline Roof slab & 3.68 & 4 & 3.67 & 4 & 3.65 & 21 & 3.80 & 2 & 3.73 & 4 & 3.96 & 3 \\
\hline Internal painting & 3.66 & 5 & 3.55 & 6 & 3.78 & 14 & 3.43 & 12 & 3.61 & 8 & 3.94 & 4 \\
\hline \multirow{2}{*}{$\begin{array}{l}\text { Clean water supply } \\
\text { Block walls / internal } \\
\text { partitions }\end{array}$} & 3.66 & 5 & 3.19 & 17 & 3.75 & 15 & 3.46 & 11 & 3.54 & 10 & 3.47 & 22 \\
\hline & 3.65 & 7 & 3.80 & 1 & 3.92 & 7 & 3.81 & 1 & 3.57 & 9 & 3.75 & 10 \\
\hline Air circulation & 3.63 & 8 & 2.93 & 24 & 4.60 & 1 & 3.67 & 5 & 3.78 & 1 & 3.89 & 6 \\
\hline Water supply & 3.62 & 9 & 3.26 & 14 & 3.63 & 22 & 3.04 & 20 & 2.86 & 27 & 2.62 & 28 \\
\hline External painting & 3.60 & 10 & 3.55 & 6 & 3.77 & 17 & 3.31 & 13 & 3.46 & 14 & 3.71 & 13 \\
\hline Nettings & 3.57 & 11 & 3.01 & 23 & 3.37 & 26 & 3.52 & 8 & 3.39 & 15 & 3.78 & 9 \\
\hline Doors & 3.56 & 12 & 3.35 & 13 & 3.72 & 16 & 3.28 & 14 & 3.74 & 3 & 3.73 & 11 \\
\hline \multirow{2}{*}{$\begin{array}{l}\text { Windows } \\
\text { Columns and } \\
\text { beams }\end{array}$} & 3.56 & 12 & 3.52 & 8 & 3.69 & 19 & 3.61 & 6 & 3.69 & 6 & 3.89 & 6 \\
\hline & 3.53 & 14 & 3.48 & 10 & 3.79 & 13 & 3.52 & 8 & 3.31 & 18 & 3.79 & 8 \\
\hline Security & 3.53 & 14 & 3.23 & 15 & 3.88 & 9 & 3.17 & 17 & 3.28 & 19 & 3.51 & 21 \\
\hline Sanitary appliances & 3.52 & 16 & 3.41 & 11 & 3.53 & 23 & 2.96 & 23 & 3.36 & 17 & 3.53 & 19 \\
\hline \multirow{2}{*}{$\begin{array}{l}\text { Floor / wall tiles } \\
\text { Electricity supply } \\
\text { (lighting) }\end{array}$} & 3.52 & 16 & 3.50 & 9 & 3.51 & 24 & 3.06 & 19 & 3.51 & 11 & 3.16 & 27 \\
\hline & 3.51 & 18 & 3.17 & 18 & 3.83 & 11 & 2.81 & 25 & 2.92 & 25 & 3.65 & 16 \\
\hline Garbage disposal & 3.50 & 19 & 3.12 & 20 & 3.30 & 27 & 3.02 & 21 & 2.88 & 26 & 3.59 & 18 \\
\hline \multirow{2}{*}{$\begin{array}{l}\text { Ceiling } \\
\text { Water waste } \\
\text { disposal }\end{array}$} & 3.45 & 20 & 3.77 & 3 & 3.67 & 20 & 3.72 & 4 & 3.72 & 5 & 4.09 & 2 \\
\hline & 3.39 & 21 & 3.15 & 19 & 3.50 & 25 & 3.19 & 16 & 3.11 & 24 & 3.30 & 25 \\
\hline Drains & 3.33 & 22 & 3.23 & 15 & 3.70 & 18 & 3.20 & 15 & 3.14 & 23 & 3.36 & 24 \\
\hline \multirow{2}{*}{$\begin{array}{l}\text { Fire protection } \\
\text { Human traffic } \\
\text { control }\end{array}$} & 3.28 & 23 & 2.58 & 26 & 3.84 & 10 & 2.59 & 26 & 3.39 & 15 & 3.72 & 12 \\
\hline & 3.25 & 24 & 2.68 & 25 & 3.89 & 8 & 2.87 & 24 & 3.15 & 22 & 3.63 & 17 \\
\hline \multirow{2}{*}{$\begin{array}{l}\text { Humidity control } \\
\text { Telecommunication } \\
\text { systems }\end{array}$} & 3.15 & 25 & 3.05 & 22 & 4.20 & 2 & 3.00 & 22 & 3.18 & 21 & 3.46 & 23 \\
\hline & 3.15 & 26 & 2.30 & 27 & 3.80 & 15 & 2.46 & 27 & 3.49 & 12 & 3.66 & 13 \\
\hline $\begin{array}{l}\text { Noise protection } \\
\text { Vertical }\end{array}$ & 3.14 & 27 & 3.08 & 21 & 4.02 & 5 & 3.07 & 18 & 3.49 & 12 & 3.53 & 19 \\
\hline transportation & 1.50 & 28 & 1.44 & 28 & 2.78 & 28 & 1.30 & 28 & 2.59 & 28 & 3.25 & 26 \\
\hline
\end{tabular}

supply, and telecommunication systems are rated above average in their performance. The building structure and fabric are all ranked very low in their state of maintenance; however they are above average in performance while the garbage disposal/ waste disposal are rated average in performance. This is also an indication that much resources are still needed from government to improve their standard especially in the area of building structure and fabric for effective healthcare delivery.

\section{OSUN STATE}

The building structure and fabric are found to be above average in performance and they are equally rated best among other attributes considered. There is adequate provision for air circulation for effective performance. The sanitation of the environment based on the level of cleanliness is found to be above average in its state of maintenance. The entire building services (i.e. water supply, waste disposal, security the drains, noise protection, garbage disposal and humidity control) are rated average in performance. The control of human traffic, electricity supply, fire protection and telecommunication systems are all rated below average. The use of lifts is rated very bad in its state of maintenance. It is ranked lowest among others.
This is evidence that government needs urgent attention to avert the collapse of the facilities meant for effective healthcare delivery. It is true that good patient care comes from dedicated individuals; it is equally true that the physical structures and hospital environment must be such that the safety and well being of patients is protected.

\section{EKITI STATE}

The arrangement of the hospitals' built environment creates adequate air circulation for effective performance. It is rated above average in performance. The surroundings are rated above average considering the level of cleanliness. The building structure and fabric are above average in their state of maintenance. Services such as telecommunication systems, noise protection, fire protection, humidity control, human traffic control, drains and waste disposal are average in performance. This electricity supply, water supply garbage disposal, and vertical transportation are below average in performance. They are ranked lowest among others. This is also an indication that more resources are needed for effective healthcare delivery as the physical environment in which patients receive care affects patient recovery, staff satisfaction and organisation productivity. 


\section{ONDO STATE}

The building structure and fabric are rated good in performance and they are rated best among others in their state of maintenance. Services such as fire protection, telecommunication systems, electricity supply, human traffic control, noise protection and sanitary appliances are all rated above average in performance. The security of the surroundings, water supply, humidity control, the drains, waste disposal and the use of lifts are rated average in performance. They are all ranked low among other attributes considered. This is an indication that more resources are needed from government for effective health care delivery.

\section{SUMMARY OF FINDINGS}

The study revealed that in Southwest Nigeria the state of maintenance of public hospital buildings including services are above average in their operational performance. Structure and fabric (i.e. block walls, floor slabs, beams and columns and roof structure) were highly rated among others in their operational state. Buildings were well located therefore creating sufficient air circulation for efficient performance of the operations. The majority of public hospitals have their environment well sanitised with good clean water supply. Most of the internal elements (i.e. painting, wall/floor tiles, doors, ceiling and windows) were found also to be above average in their operational state. There is humidity control an d good protection from noise. Among other variables rated very low in their performance were the uses of lifts (vertical transportation), fire protection, telecommunication systems and electricity supply. Both the Federal and State-owned hospitals rated structure and fabric very high in their performance. Both rated the use of lifts, telecommunication systems, electricity supply, and sanitary fittings very low in their performance. From the hypothesis tested, it was revealed that there is a significant difference in the operational state of buildings including services between the Federal and State-owned hospitals in Southwest Nigeria.

\section{CONCLUSION}

In the light of the research findings, the following recommendations are made in order to improve the state of maintenance of public hospital buildings including services in Southwest Nigeria:

- Government should provide necessary resources to ensure the functionality of the services so as to improve users' satisfaction. Maintenance staffs are to be well motivated in order to deliver their best during maintenance work execution. Management should ensure that the heads of maintenance departments possess the required skills for the maintenance management of their hospital facilities. A progress report of work done is to be submitted to management through the heads of maintenance departments.

- Policies and strategies provide the modus operandi for organisational performance. For optimum results, maintenance departments need to adopt sound policies with respect to building elements/services replacement. This will provide an appropriate basis for preparing budgets that meet the actual maintenance needs of the hospital buildings and services included. Maintenance managers are to do their best to prepare realistic need-based budgets while the government should make efforts to increase the funding for hospital maintenance.
- Government should encourage individuals or other stakeholders to contribute towards healthcare delivery services since government intervention alone can no longer be sufficient to meet needs, particularly due to the high demand of contemporary developments in healthcare technology.

- Inefficiencies and inflexibility through bureaucratic impediments to operational performance should be avoided in hospital environments due to the sensitivity of the services being rendered.

- Maintenance staff and users of hospital buildings should be given opportunities for further training on their jobs and on effective use of hospital facilities. This is necessary to reduce the occurrence of defects, which will consequently bring about better physical and functional hospital building elements and services.

\section{ACKNOWLEDGEMENTS}

The authors acknowledged the central Research Committee of the University of Lagos for the financial support given through research grant CRC No. 2006/05 that facilitated this research work.

\section{REFERENCES}

Adebayo, S.O. (1991) 'A study of the maintenance management of public buildings in Nigeria', Unpublished PhD thesis, Nigeria: University of Lagos.

Arditi, D. (1997) 'Issues in building maintenance: property managers' perspective', Journal of Architectural Engineering, 5(4) 117-127.

Chanter, B. and Swallow, P. (1996) Building maintenance management, Blackwell Scientific.

Chartered Institution of Building (1975) Maintenance management, Englemere.

Dilani, A. (1999) 'Design and care in hospital planning', Unpublished PhD thesis, Sweden: Karolinska Institute.

Estates Good Practice (2005) 'Strategic approach to best maintenance practices for public buildings in Nigeria', The Journal of the Association of Housing Corporation of Nigeria, 1(8), 20-29.

Gregerson, J. (1994) 'Opportunity knocks for facilities consultants', Building Design and Construction, 35(12), 48-52.

Hardy, O.B. and Lammers, L.P. (1996) Hospitals: the planning and design process, Aspen Publishers.

Holland, B.K. (1987) 'Managing a single family home', The Institute of Real Estate Management (Chicago), 20(15), 4-9.

lyagba, R.O.A. (2005) 'The menace of sick buildings: a challenge to all for its prevention and treatment', An Inaugural Lecture delivered at University of Lagos, Lagos.

Johassen, J., Klemenic, R., and Leinenwever, M. (2001) Health facility flexibility and humanity: an agenda for the 21st century, Stockholm. 
Kliment, S. (2000) Building type, basics for healthcare facilities, John Wiley and Sons.

Lee, R (1987) Building maintenance management, Blackwell Science Ltd.

Nous Hospital Consultants (2002) Generating the master plan for hospitals, Leading Hospital and Health Care Management Consultants of India.

Oladapo, Y. (2005) 'Evaluation of the maintenance management of the staff housing estates of selected first generation Universities in South-West, Nigeria', Unpublished PhD thesis, Nigeria: Obafemi Awolowo University.

Onifade, K. (2003) 'Informatics in hospital management', Unpublished MSc report, Nigeria: University of Lagos.

Seeley, I.H. (1987) Building maintenance, Macmillan Press.

Shohet, I.M. (2003) 'Building evaluation methodology for setting maintenance priorities in hospital buildings', Construction Management and Economics, 21(3), 681-692.

Smith, R. (2003) 'Best maintenance practices', Journal for Maintenance and Maintenance Management, 16(1), 10-15.

Stolzenberg, E.A. (2002) Governance change for public hospitals (available from http://www.ache.org/membership/advtofellow/ caserpts/governance99.cfm).

Streifel, A.J. (2002) Infection control factors in hospital building maintenance and operations, Department of Environmental Health and Safety, University of Minnesota.

Ulrich, R. (1992) 'Garden in health care facilities: uses, therapeutic benefits and design', in proceedings of The Therapeutic Environments Formum, Healing Environments Virtual Seminar. 